\title{
MODEL BISNIS YANG BAIK DAN BERTUHAN
}

\author{
I Wayan Bayu Diatmika
}

\author{
Pasca Sarjana Fakultas Ekonomi dan Bisnis Universitas Brawijaya \\ Jl. Mayjen Haryono 165 Malang \\ Email: bayudiatmika@gmail.com
}

Abstract

Business practices currently doctrine strongly by capitalist ideology. Business applied to get the optimal profits, no matter how do they obtain it. At the end, businesses increasingly move with concern on their own profit and do not concern on other parties who are affected by the business. The business orientation as this model will only give pleasures to the owner of business. This article discusses on the new model that reconstruct the capitalistic (conventional) business. New business model formed by combining the triple bottom line (TBL), tri hita karana (THK), Pancasila ideology, and the full disclosure based on the ethics that refers to the deontology theory. The combination of those concepts form the new business model that arranged by three foundation which connected each other that are basic foundation, then the fundamental foundation, and the last was the full disclosure foundation. The basic foundation of the business model is the concept of ethics deontology which came through good intentions. The good intentions were then be backed by fundamental foundation that is a combination of triangle TBL and THK. The culmination of a combination of TBL and THK welfare is the creation that is the root of pro human, nature, advantages, and the God.The last foundation, the full disclosure, like a flowers that bloom from the bushes, this is visualize business that will be seen by public through information that distributed by the business. The core of the notion of the business model is essentially on the foundation, namely deontologist approach, or approach based on good intentions action or obligation to follow the God values. As strong as any business model organized, good intentions are the only bricks strongest to it.

Keywords: business model, capitalist, god, ethics deontology theory, tri hita karana, triple bottom line, pancasila ideology, full disclosure 
Abstrak

Praktik bisnis saat ini didoktrin kuat oleh ideologi kapitalis. Bisnis dijalankan untuk memperoleh keuntungan yang sebesar-besarnya, tidak peduli dengan cara apa keuntungan tersebut didapatkan. Pada akhirnya, bisnis kian bergerak dengan hanya mementingkan kepentingannya atas keuntungan dan tidak mempedulikan kepentingan dari pihak-pihak lain yang dipengaruhi oleh bisnis tersebut. Orientasi bisnis seperti ini pada akhirnya hanya akan memberikan kenikmatan kepada pemilik-pemilik dari bisnis tersebut.Artikel ini membahas mengenai suatu model baru yang merekonstruksi model bisnis kapitalistik (konvensional). Model bisnis baru dibentuk dengan mengkombinasikan konsep triple bottom line (TBL), tri hita karana (THK), ideologi Pancasila, dan pengungkapan penuh dengan berdasarkan pada landasan etika sesuai dengan teori deontologi. Pengkombinasian dari konsep-konsep tersebut melahirkan suatu model bisnis baru yang tersusun dari tiga pondasi yang saling berkaitan satu dengan lainnya yakni pondasi dasar atau basic foundation, kemudian pondasi fundamental atau fundamental foundation, dan yang terakhir adalah pondasi konsep pengungkapan penuh.Pondasi dasar dari model bisnis ini ialah konsep etika deontologi yang diturunkan melalui niat baik. Niat baik tersebut kemudian akan disokong oleh pondasi fundamental yang merupakan kombinasi dari segitiga TBL dan THK. Puncak dari kombinasi dari TBL dan THK ialah terciptanya kesejahteraan yang merupakan akar dari keberpihakan terhadap manusia, alam, keuntungan, dan Tuhan. Pondasi terakhir, konsep pengungkapan penuh, ibarat bunga yang mekar dari pohonnya, inilah visualisasi bisnis yang akan dapat dilihat oleh publik melalui informasi-informasi yang disebarkan oleh bisnis. Inti dari gagasan model bisnis ini ialah pada pondasi dasarnya, yakni pendekatan deontologis, atau pendekatan tindakan berdasarkan niat baik atau kewajiban untuk mengikuti nilai-nilai firman Tuhan. Sekuat apa pun model bisnis ini disusun, niat baik adalah satu-satunya batu bata terkuat untuk menopangnya.

Kata kunci: model bisnis, kapitalis, tuhan, teori etika deontologi, tri hita karana, triple bottom line, ideologi pancasila, pengungkapan penuh

\section{PENDAHULUAN}

Profit is everything here. Keuntungan adalah segalanya. Inilah ungkapan yang dipegang teguh oleh bisnis saat ini. Ungkapan tersebut terlahir dan tumbuh kuat sebagai orientasi bisnis saat ini akibat dari dampak ideologi kapitalis.Hal ini tampak dengan jelas dengan melihat kecilnya perhatian bisnis untuk berkontribusi kepada lingkungan sosial dan alam yang ada di sekitarnya padahal pihak-pihak tersebutlah yang secara tidak langsung menikmati dampak negatif dari operasi bisnis di daerah mereka. Dengan dalih efisiensi biaya, kepentingan buruh dan karyawan untuk berhak sejahtera diabaikan oleh bisnis. Buruh dan karyawan dipaksa 
untuk berkerja mati-matian dan loyal kepada bisnis namun dengan tanpa timbal balik mensejahterakan buruh dan karyawan.Hal yang sama juga dialami oleh alam, khususnya alam yang dipergunakan untuk ekploitasi oleh bisnis ataupun alam yang terkena dampak secara tidak langsung akibat operasional bisnis. Bisnis mengeksploitasi mereka besar-besaran, dengan begitu keuntungan yang didapat akan lebih besar, namun bisnis seakan lupa untuk mengembalikan kelestarian alam yang dieksploitasinya. Bisnis mungkin saja tidak secara langsung memanfaatkan lingkungan alam yang ada di sekitarnya namun dampak dari operasi bisnis secara tidak langsung mempengaruhi kualitas hidup dari alam tersebut. Limbah industri, polusi udara, pencemaran, merupakan contoh-contoh dari dampak yang disebabkan oleh bisnis dengan tanpa mengeksploitasi alam secara langsung. Dari sekian banyak dampak yang disebabkan oleh bisnis akibat operasinya, pada akhirnya segala eksploitasi bisnis kepada manusia dan alam hanya akan menjadi tabungan kehancuran bagi alam semesta ini yang ketika tiba waktunya secara bersama-sama, bisnis, manusia, dan alamlah yang akan menikmati konsekuensi dari kerakusan bisnis tersebut.

Hal ini adalah masalah besar apabila terus dibiarkanberlanjut. Model bisnis perlu dirombak dan disusun kembali agar mampu bergeser dari orientasi keuntungan. Manusia harus diberikan kembali haknya untuk merasakan hidup yang lebih sejahtera. Alam pun demikian, alam harus diberikan kesempatan untuk menyeimbangkan, harus diberikan kesempatan untuk memulihkan diri dan harus dijaga kelestariannya. Bisnis harus diarahkan kembali pada nilai-nilai ketuhanan dan nilai etis. Artikel ini bertujuan untuk membentuk kembali model bisnis baru yang lebih baik, bernilai etis dan mengandung nilai ketuhanan. Artikel ini bertujuan untuk menyusun sebuah model bisnis baru dengan menyelaraskan Pendekatan Teori Etika Deontologis, Konsep Triple Bottom Line, Konsep Tri Hita Karana, Ideologi Pancasila dan Konsep Pengungkapan Penuh. Model bisnis harus disusun dengan pendekatan yang implikatif dan mengandung nilai-nilai budaya luhur bangsa sehingga mampu mewujudkan suatu model bisnis yang baik. Model bisnis tersebut tidak hanya baik namun juga telah menyertakan Tuhan di dalamnya.

\section{PEMBAHASAN}

"Pada akhirnya, niat baiklah yang kemudian menjadi pondasi terpenting dalam mewujudkan sebuah model bisnis yang baik dan bertuhan"

Model bisnis yang disusun di dalam artikel ini merupakan penyelarasan dari beberapa konsep yang kemudian disusun dalam tiga pondasi yakni pondasi dasar, fundamental dan luar. Pembahasan artikel ini akan memuat tentang ketiga pondasi tersebut dan peta konsep dari model bisnis baru yang disebut di dalam artikel ini sebagai model bisnis yang baik dan bertuhan. 


\section{Pondasi I: Pondasi Dasar (Basic Foundation)}

\section{Teori Etika Deontologi}

Istilah "deontologi" berasal dari kata Yunani, yakni dari urat kata deon yang berarti kewajiban. Teori deontologi menggunakan pendekatan bahwa baik buruknya perbuatan didasarkan pada kewajiban. Kewajiban yang dimaksud di sini sering dikaitkan dengan konteks agama, yakni menjelaskan mengenai perbuatan apa yang harus dilakukan dan tidak boleh dilakukan. Deontologis menolak pendekatan konsekuensi atau timbal balik sebagai dasar dalam membangun pertimbangan mengenai suatu konsepsi mengenai perbuatan yang baik dan buruk. Jika suatu perbuatan dilakukan dengan pertimbangan timbal balik manfaatyang dapat diperoleh ke depannya, menurut teori deontologi perbuatan tersebut bisa menjadi suatu perbuatan yang tidak etis. Misalnya saja, suatu bisnis memutuskan untuk menjual ganja. Penjualan ganja sangat menguntungkan. Berdasarkan teori deontologis, kegiatan bisnis ganja dipandang sebagai kegiatan yang tidak etis, karena kegiatan tersebut hanya mempertimbangkan timbal balik yang diperoleh, selain itu, kegiatan perjualan ganja tergolong kegiatan yang ilegal dan haram sehingga kegiatan tersebut sangat bertentangan dengan konsep teori deontologi.

Dasar dari teori etika deontologi diberikan oleh filsuf besar dari Jerman, Immanuel Kant (1734-1804). Menurut Kant, perbuatan dikatakan baik jika dilakukan dengan landasan kewajiban untuk dilakukan, memang seharusnya dilakukan sebagai manusia, tanpa mementingkan manfaat yang dinikmati di kemudian hari. Kant menyatakan bahwa suatu perbuatan baik juga merupakan perbuatan yang dilakukan begitu saja tanpa syarat apapun dengan sering dikaitkan dengan konteks perintah Tuhan kepada manusia. Hal ini disebut dengan "imperatif kategoris". Oleh karena itulah, teori deontologi sangat erat dengan konteks perbuatan yang dapat diterima dan tidak dapat diterima oleh Tuhan.

Teori deontologi menurut Kant juga menekankan pada kemauan baik dari seseorang. Kemauan baik atau niat baik adalah syarat mutlak untuk bertindak secara moral. Dalam berbagai hal, bisa saja akibat dari suatu tindakan adalah baik namun kalau tindakan tersebut tidak dilakukan dengan dasar kemauan baik untuk menaati hukum moral yang merupakan kewajiban seseorang maka tindakan tersebut dapat dipandang sebagai suatu tindakan yang etis. Atas dasar tersebut, menurut Kant, tindakan yang baik adalah tindakan yang tidak saja sesuai dengan kewajiban melainkan juga dijalankan berdasarkan niat baik sebagai manusia. Konsekuensinya, ia menolak semua tindakan yang bertentangan dengan kewajiban sebagai tindakan yang baik bahkan walaupun tindakan tersebut tidak berguna. Demikian pula, semua tindakan yang dijalankan sesuai dengan kewajiban tetapi tidak dijalakan berdasarkan kemauan yang baik melainkan hanya karena dipaksa atau terpaksa dianggapnya sebagai tindakan yang tidak baik atau tidak etis (Keraf, 1998). 


\section{Teori Etika Deontologi sebagai Pondasi Dasar (Basic Foundation) Model Bisnis}

Deontologi mengaitkan nilai moral pada makna dari suatu perbuatan, mana perbuatan yang bernilai baik dan mana perbuatan yang bernilai buruk. Teori etika deontologi menekankan pada niat baik dalam melakukan sesuatu. Niat baik tersebut dapat dikaitkan dengan kewajiban manusia dalam memandang firman Tuhan. Niat baik dapat dikaitkan dengan pertimbangan nurani manusia dalam memandang apa yang seharusnya memang dilakukan dan apa yang seharusnya tidak boleh dilakukan. Walaupun suatu tindakan nantinya akan menghasilkan hasil atau timbal balik yang baik, namun tindakan tersebut tidak disertai dengan niat baik sebelumnya, maka tindakan tersebut dapat dipandang tidak etis. Tindakan yang menghasilkan hasil yang baik namun bertentangan dengan kewajiban manusia akan firman Tuhan atau nilai moralitas juga dikatakan sebagai suatu tindakan yang etis. Jadi, inti dari pendekatan teori deontologis ialah pada nilai niat baik yang terkandung di dalam suatu tindakan dan bukan pada hasil atau timbal balik yang akan didapatkan dari suatu tindakan (Bertens, 2000), (Keraf, 1998).

Dalam mewujudkan model bisnis yang baik dan bertuhan, bisnis harus diawali dengan niat baik sebelumnya. Niat baik ini dapat diturunkan dalam pertimbangan bisnis untuk mengembangkan komunitas dan lingkungan menjadi lebih baik (Ahlstrom, 2010). Implementasinya dapat dikuatkan dengan pendekatan pada nilai ideologi Pancasila sila pertama yakni Ketuhanan yang Maha Esa. Salah satu cara termudah menentukan niat baik ialah dengan menyertakan Tuhan dalam niat tersebut. Sila pertama Pancasila mengarahkan bisnis pada perhatian untuk selalu menyertakan Tuhan pada menentukan arah dan bagaimana bisnis berjalan. Bila Tuhan selalu disertakan, bisnis akan selalu mampu mempertimbangkan niat baik dalam menentukan praktiknya. Menyertakan Tuhan bersifat universal, tidak terbatas pada agama, melainkan pada nilai spiritual manusia dalam memandang Tuhan (Fry \& Slocum Jr., 2008).

Konsep ini sangat penting untuk dipegang teguh untuk mewujudkan suatu model bisnis yang baik dan bertuhan. Konsep ini adalah pondasi pertama atau pondasi yang paling dasar (basic foundation) dalam menciptakan model bisnis yang baik dan bertuhan. Apabila konsep ini tidak mampu dipegang, bisnis tetap akan menjauh pada nilai kebaikan dan ketuhanan. Layaknya sebuah pohon, konsep ini ialah akar dari pohon tersebut. Akar harus kuat agar pohon tersebut tetap kokoh berdiri, begitu pula dengan konsep ini, ia harus dipegang teguh agar model bisnis yang baik dan bertuhan dapat tercipta. 


\section{Pondasi II: Pondasi Fundamental (Fundamental Foundation)}

\section{Konsep Triple Bottom Line (TBL)}

Dalam buku Cannibals with Forks: The Triple Bottom Line of 21st Century Business (Elkington, 2004), Elkington memperkenalkan formulasi 3P sebagai pendekatan dalam konsep TBL, yakni people, planet and profit (Elkington, 2004). Formulasi itu merupakan turunan dari konsep TBL itu sendiri, bahwa bisnis harus memfokuskan perhatiannya kepada pilar manusia, planet, dan keuntungan. Perhatian kepada ketiga pilar haruslah harmonis dan seimbang, sehingga kelak bisnis akan memperoleh suatu sustainability development atau perkembangan yang berkelanjutan.

Konsep TBL mengusung orientasi pada suatu sustainability development atau perkembangan yang berkelanjutan. Pendekatan ini mencerminkan suatu peningkatan pada kesejahteraan komunitas (manusia), berkurangnya dampak terhadap lingkungan atau alam, dan meningkatnya pertumbuhan ekonomi dari perusahaan (Rogers \& Ryan, 2001). Pembangunan berkelanjutan merupakan suatu proses pembangunan yang berusaha untuk memenuhi kebutuhan (segala sesuatu yang kita nikmati) sekarang dan selanjutnya diwariskan kepada generasi mendatang. Jadi, dengan pola pembangunan berkelanjutan generasi sekarang dan generasi yang akan datang mempunyai hak yang sama untuk menikmati alam beserta isinya ini (Subadra \& Nadra, 2006).

\section{Konsep Tri Hita Karana (THK)}

Dalam nilai budaya yang berkembang di Bali, ada suatu konsep yang disebut dengan tri hita karana. Tri berarti tiga, hita berarti suatu kesejahteraan, dan karana berarti penyebab (Subadra \& Nadra, 2006), (Krishna, 2010). Jadi bila diartikan secara keseluruhan, Tri Hita Karana atau THK merupakan tiga jalan untuk mewujudkan kesejahteraan. THK terdiri dari tiga jalan atau pilar, yakni: parahyangan, pawongan dan palemahan. Parahyangan berarti berhubungan baik dengan Tuhan. Pawongan berarti berhubungan baik dengan manusia di sekitarnya. Palemahan berarti berhubungan baik dengan lingkungan atau alam di sekitar. Jadi intinya, untuk mencapai suatu kesejahteraan, berdasarkan konsep THK, manusia haruslah menjaga hubungan baiknya dengan Tuhan, dengan manusia lain yang ada di sekitarnya, dan pada alam dan lingkungan yang digunakan sebagai tempat tinggal dan sumber kehidupan.

\section{Keselarasan Konsep Triple Bottom Line dan Tri Hita Karana}

TBL dan THK sama-sama memiliki tiga pilar. Dua Pilar yang selaras antara Konsep TBL dan THK ialah pilar fokus pada manusia dan fokus pada alam atau planet. Dua Konsep tersebut mengedepankan pada pendekatan bisnis yang 
menekankan pada perhatian untuk mengedepankan nilai kesejahteraan manusia sebagai upaya bisnis untuk menjaga hubungan baiknya dengan manusia yang terlibat di dalam bisnis ataupun ada di sekitar bisnis dan ikut dipengaruhi oleh keberadaan dari bisnis tersebut. Kemudian pilar fokus pada kelestarian alam atau planet, pilar ini mengedepankan perhatian bisnis kepada nilai-nilai pertangggungjawaban bisnis kepada alam karena telah memanfaatkan sumber daya alam yang telah diberikan oleh alam untuk diolah di dalam bisnis. Fokus pada kelestarian alam merupakan upaya bisnis dalam menjaga hubungan baik bisnis dengan alam. Dua pilar dari THK dan TBL tersebut merupakan pondasi yang kuat bagi bisnis untuk mencapai sustainability development seperti yang dijelaskan oleh Elkington (1997), selain fokus bisnis dalam mencari keuntungan. Sustainability development merupakan sebuah proses dan sistem pengembangan yang bisa menjamin keberlangsungan atau keberadaan sumberdaya alam, kehidupan sosial dan ekonomi, dan budaya ke generasi yang akan datang ((Ardika, 2003:9) dalam (Subadra \& Nadra, 2006)).

Kemudian pilar ketiga dari TBL, ialah keuntungan, merupakan pilar puncak yang mengantarkan keselarasan antara konsep TBL dan THK. THK mengusung tiga pilar yang dapat dijalankan sebagai upaya menuju kebahagiaan dan kesejahteraan, yakni menjaga hubungan yang baik dengan manusia, alam, dan Tuhan. Keselarasan konsep TBL dan THK menekankan bisnis pada perhatian dalam mencari keuntungan yang dapat dipertanggungjawabkan (responsible profit) kepada Tuhan. Bisnis dalam menjaga hubungan baiknya dengan Tuhan harus menekankan perhatian pada pencarian keuntungan (pilar TBL) yang dapat diterima oleh Tuhan dan dihalalkan oleh Tuhan sehingga suatu hubungan yang baik dengan Tuhan dapat diwujudkan oleh bisnis tersebut (pilar THK). Pendekatan ini menolak keberadaan dari keuntuntungan yang bersifat haram dan diperoleh dengan cara yang tidak etis.

\section{Implementasi Konsep TBL dan THK dalam Model Bisnis}

Bisnis merupakan kegiatan ekonomis. Bisnis dari sudut pandang ekonomi berarti melakukan serangkaian kegiatan dengan bertujuan untuk mencari hasil atau keuntungan. Terlepas dari dua sudut pandang lainnya, yakni sudut pandang aspek hukum dan nilai etika dan moral, bisnis pada dasarnya dijalankan pada motif untuk mencari keuntungan, oleh karena itu, bisnis tidak akan terlepas dari pandangan pencarian keuntungan. Namun, perlu diingat bahwa keuntungan adalah bukan suatu tujuan puncak yang mampu menghantarkan bisnis pada puncak kesejahteraan. Elkington (2004) menjelaskan bahwa orientasi yang lebih baik dikedepankan oleh bisnis adalah orientasi pada sustainability development atau perkembangan yang berkelanjutan.

Perkembangan yang berkelanjutan mencakup pula pertumbuhan keuntungan di dalamnya namun diperluas dengan penekanan pada perhatian atas kepentingan manusia dan alam, yang dikenal pula dengan profit, people and planet $(\mathrm{P} 3)$ dalam Konsep TBL. Keuntungan yang diperoleh oleh bisnis haruslah sudah memperhatikan 
pada aspek kepentingan manusia dan alam. Jadi, bisnis yang baik memiliki orientasi bukan lagi hanya pada keuntungan, melainkan pada sustainability development yang akan membawa bisnis pada keberlangsungan hidup dan pertumbuhan yang lebih baik dan mencerminkan pemenuhan kepentingan manusia dan alam yang berada di sekitar bisnis (Subadra \& Nadra, 2006).

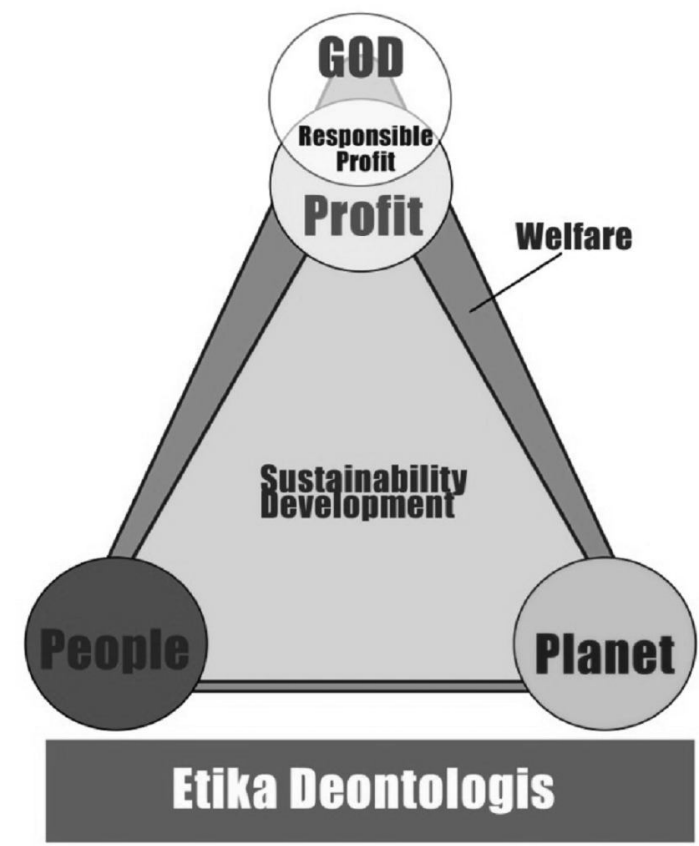

\section{Gambar 1. Perpaduan Konsep THK dan TBL dengan Teori Etika Deontologis sebagai Dasar Pondasinya}

Dalam mewujudkan sustainability development, konsep THK menekankan bisnis pada batasan mengenai keuntungan yang dihasilkan. Keuntungan yang diusung oleh konsep TBL haruslah keuntungan yang bersifat halal, tidak ilegal, dan etis, sehingga keuntungan tersebut dapat dipertanggungjawabkan kepada Tuhan (responsible profit), sesuai dengan pendekatan konep THK. Perpaduan antara konsep TBL dan THK akan mengeliminasi dan melarang bisnis untuk menghasilkan keuntungan yang haram, diperoleh dari tindakan yang tidak etis, dan melanggar hukum yang berlaku. Konsep responsible profit sesuai dengan tiga aspek bisnis yang dijelaskan oleh (Bertens, 2000) bahwa bisnis yang baik adalah bisnis yang selain mencari keuntungan juga harus mengendepankan pada aspek legalitas atau hukum serta dibangun dan dijalankan oleh dasar nilai etika dan moral. Hal ini dikuatkan dengan pondasi dasar yakni Teori Etika Deontologis yang di mana menjelaskan bahwa keuntungan yang etis dalah keuntungan yang dihasilkan dari prilaku baik dan sesuai dengan kewajiban yang difirmankan oleh Tuhan. Keuntungan yang 
etis adalah keuntungan yang dihasilkan dari prilaku etis, sesuai dengan pendekatan teori deontologis, yang kemudian dapat dipertanggungjawabkan kepada Tuhan, sehingga suatu hubungan baik dengan Tuhan dapat dijaga. Menjaga hubungan baik dengan Tuhan atau parahyangan merupakan salah satu pilar untuk mencapai suatu kesejahteraan atau welfare, sesuai dengan konsep THK, yang dalam kajiannya lebih luas dan mencakup di dalamnya sustainability development dari konsep TBL.

Dalam konteks yang lebih luas, responsible profit yang dimaksud ialah keuntungan yang tidak hanya memperhatikan pada aspek ekonomi dari bisnis tersebut saja namun juga memperhatikan pada aspek kepentingan dari kesejahteraan manusia dan kelestarian alam. Responsible profit tidak akan dicerminkan oleh keuntungan yang dihasilkan dari praktik bisnis yang merugikan kesejahteraan manusia serta merusak kelestarian alam. Oleh karena itu, responsible profit haruslah dibangun dari pendekatan bisnis pada kesejahteraan manusia (people - pawongan) dan kelestarian alam (planet - palemahan) sesuai dengan dua pilar dari konsep TBL dan THK. Muara dari pendekatan tersebut ialah terciptanya suatu hubungan yang baik antara bisnis dengan manusia dan alam di sekitarnya yang akan memberikan kontribusi pada kesejahteraan yang mencakup di dalamnya sustainability development dan pertumbuhan keuntungan. Gambar 1 menunjukkan bagaimana peta konsepdalam memadukan antara Konsep THK dan TBL.

\section{Konsep TBL dan THK sebagai Pondasi Fundamental (Fundamental Foundation) Model Bisnis}

Bisnis yang baik adalah bisnis yang memiliki keberpihakan terhadap niat baik dan bukan pada konsekuensi atau timbal balik yang didapatkan (etika deontologis) (Keraf, 1998). Bisnis yang baik akan mencerminkan suatu bisnis yang bertuhan, dalam artian bisnis tersebut memiliki suatu hubungan yang baik dengan Tuhan (parahyangan). Hubungan baik dengan Tuhan akan tercermin dari niat baik bisnis, yang menurunkan suatu praktik bisnis yang baik, dimana praktik bisnis yang baik tersebut tidak akan terlepas dari perhatian untuk mewujudkan suatu hubungan yang harmonis dengan manusia dan alam (pawongan dan palemahan). Hubungan yang harmonis dengan manusia dan alam ini kemudian menciptakan suatu perhatian pada fokus untuk mensejahterakan manusia dan melestarikan lingkungan atau alam (peopleandplanet). Akhirnya, dari keseluruhan praktik bisnis yang baik tersebut, bisnis akan memperoleh suatu keuntungan, di mana keuntungan ini bersifat halal, tidak haram, tidak ilegal, sehingga mampu dipertanggungjawabkan (responsible profit) kepada Tuhan. Responsible profit ini mencerminkan pula suatu hubungan yang baik kepada Tuhan (parahyangan). Dari fokus terhadap pencarian responsible profit, fokus untuk mensejahterakan manusia dan melestarikan alam, bisnis akan memperoleh suatu welfare atau kesejahteraan (Krishna, 2010), di mana di 
dalamnya akan terdapat suatu sustainability development seperti yang dikatakan oleh Elkington dalam Konsep TBL. Perpaduan antara Konsep TBL dan THK ini merupakan suatu pondasi fundamental.

Gambar di atas merupakan peta konsep dari perpaduan antara konsep THK dan TBL, di mana dalam perpaduan tersebut, Teori etika deontologis digunakan sebagai pondasi dasar dalam mewujudkan suatu model bisnis yang baik dan bertuhan. Seperti yang dikatakan oleh Kant (1734-1804), suatu tindakan tergolong baik atau tidak baik, didasari oleh niat baik dari orang tersebut (Keraf, 1998). Suatu model bisnis yang baik harus tercipta dari niat baik sebelumnya. Niat yang baik akan mencerminkan pemenuhan kewajiban manusia terhadap perintah Tuhan. Oleh karena itulah, teori etika deontologi digunakan sebagai dasar model bisnis yang baik dan bertuhan.

Perpaduan konsep THK dan TBL berperan sebagai pondasi kedua atau pondasi fundamental dalam menciptakan suatu model bisnis yang baik dan bertuhan. Pondasi fundamental berperan untuk menurunkan konsep dari pondasi dasar model bisnis agar dapat lebih applicable dalam praktik bisnis. Teori etika deontologi berperan sebagai pondasi dasar dalam model bisnis, perannya seperti "visi" yang dipaparkan oleh suatu perusahaan. Kemudian, agar visi tersebut dapat dijalankan, maka visi tersebut akan diturunkan ke dalam suatu "misi", inilah peran perpaduan konsep THK dan TBL sebagai pondasi kedua atau pondasi fundamental dari model bisnis yang baik dan bertuhan. Sebagai Pondasi fundamental dari model bisnis, perpaduan konsep THK dan TBL memberikan panduan dalam mewujudkan suatu praktik bisnis yang baik dan bertuhan. Pondasi ini akan sangat berguna dalam mengimplementasikan dasar etika deontologis secara nyata di dalam praktik bisnis. Pondasi ini juga akan sangat berguna untuk menyokong berjalannya nilai-nilai etis sesuai dengan etika deontologis dalam praktik bisnis.

\section{Fokus pada Kesejahteraan Manusia (People) dengan Pendekatan Ideologi Pancasila}

Fokus pada kesejahteraan manusia atau peoplemerupakan turunan dari salah satu pilar penyokong dari pondasi fundamental model bisnis yang baik dan bertuhan. Fokus ini mengedepankan pada perhatian bisnis kepada kesejahteraan manusia yang ada di sekitarnya. Manusia yang ada di sekitar bisnis bisa berupa karyawan, manajer, pemilik, investor, kreditur, pelanggan, pemerintah, masyarakat yang tinggal di sekitar bisnis tersebut dijalankan, warga negara dimana bisnis tersebut dijalankan, dan komunitas-komunitas tertentu yang dipengaruhi dan memiliki kepentingan terhadap keberadaan bisnis tersebut. Pada initinya setiap manusia yang ada di sekitar bisnis tersebut memiliki kepentingan terhadap bisnis. Karyawan misalnya, mereka memiliki kepentingan terhadap gaji dan upah yang sesuai. Pemilik bisnis memiliki kepentingan akan pertumbuhan modal yang ditanamkannya di dalam bisnis. 
Masyarakat yang tinggal di sekitar bisnis tersebut dijalankan misalnya, memiliki kepentingan salah satunya akan perhatian bisnis untuk memberikan mereka pekerjaan. Pelanggan memiliki kepentingan pada produk yang baik dan berkualitas yang dihasilkan oleh bisnis. Pemerintah memiliki kepentingan atas ditegakkannya hukum dan pembayaran pajak oleh bisnis. Banyak kepentingan yang mengikat bisnis. Manusia yang kepentingan dapat diperhatikan atau dipenuhi akan merasakan kesejahteraan. Bisnis harus mampu menyelaraskan berbagai kepentingan tersebut agar mampu memberikan kesejahteraan pada manusia yang ada di sekitarnya. Fokus pada kesejahteraan manusia harus dilandasi pada niat yang baik (Keraf, 1998) sebelumnya sehingga dalam praktiknya dapat terwujud suatu kesejahteraan bagi manusia. Hal ini sesuai dengan ideologi sila kedua hingga kelima dari Pancasila. Implementasi dari Pancasila dapat menguatkan pedoman praktis dari pondasi fundamental "Kesejahteraan Manusia" sebagai salah satu pilar penyokong dari perpaduan konsep THK dan TBL dalam model bisnis yang baik dan bertuhan.

Sila kedua dan kelima menekankan perhatian pada manusia. Hal ini merupakan pedoman praktis yang lebih menguatkan implementasi konsep fokus pada kesejahteraan manusia.

\section{Tabel 1. Pendekatan Ideologi Pancasila Sila Kedua hingga Kelima dalam Mewujudkan Fokus pada Kesejahteraan Manusia}

\begin{tabular}{|c|c|}
\hline Sila dalam Pancasila & Pendekatan Fokus pada Kesejahteraan Manusia \\
\hline $\begin{array}{l}\text { Sila Kedua } \\
\text { Kemanusiaan yang adil } \\
\text { dan beradab }\end{array}$ & $\begin{array}{l}\text { Bisnis harus mampu memberikan perhatiannya kepada seluruh elemen manusia } \\
\text { yang ada di sekitarnya, tanpa memandang status sosial atau identitas lainn ya. } \\
\text { Semua manusia harus dipandang sama dan harus disejahterakan oleh bisnis. } \\
\text { Untuk mewujudkan fokus kesejahteraan tersebut, bisnis harus melandasi }\end{array}$ \\
\hline $\begin{array}{l}\text { Keadilan sosial bagi } \\
\text { seluruh Rakyat Indonesia }\end{array}$ & $\begin{array}{l}\text { prantiknya. Dalam praktiknya, bisnis tidak boleh semena-mena dalam menjalankan } \\
\text { kegiatannya dan harus memperhatikan hak-hak orang di sekitarnya sebagai } \\
\text { manusia. Pendekatan ini akan melarang keg iatan perbudakan ataupun kegiatan } \\
\text { penggajian yang tidak sesuai pada karyawan. Pendekatan ini juga akan melarang } \\
\text { kegiatan-kegiatan penjajahan hak kekayaan alam dari suatu masyarakat, } \\
\text { manipulasi laba untuk menyenangk an pemilik, penggelapan uang pajak, dan } \\
\text { tindakan lainnya yang tidak mengedepankan pada keadilan dan kepentingan hak } \\
\text { asasi bagi orang-orang yang berkepentingan terhadap bisnis. }\end{array}$ \\
\hline $\begin{array}{l}\text { Sila Ketiga } \\
\text { Persatuan Indonesia }\end{array}$ & $\begin{array}{l}\text { Bisnis dijalankan oleh manusia dan digerakkan oleh manusia juga. Bisnis } \\
\text { membutuhkan manusia untuk terus hidup dan berkembang. Jadi, bisnis harus } \\
\text { memandang keberadaan manusia yang ada di sekitarnya sebagai suatu kesatuan. } \\
\text { Semua kepentingan orang terhadap bisnis harus diperhatikan dan diselaraskan } \\
\text { oleh bisnis untuk menentukan praktik yang seperti yang harus dilakukan oleh } \\
\text { bisnis untuk dapat mensejahterakan orang-orang tersebut. Ideologi Sila Ketiga } \\
\text { mengarahkan bisnis untuk memandang dirin ya bukan hanya sebagai satu hal } \\
\text { yang terpisah dari komunitas masyarakat, melainkan sebagai suatu kesatuan } \\
\text { dengan komunitas masyarakat, dimana semua kepentingan masyarakat terhadap } \\
\text { bisnis akan sangat menentukan bagaimana arah dan nasib dari bisnis tersebut ke } \\
\text { depannya. }\end{array}$ \\
\hline
\end{tabular}




\begin{tabular}{|c|c|}
\hline Sila dalam Pancasila & Pendekatan Fokus pada Kesejaht eraan Manusia \\
\hline $\begin{array}{l}\text { Sila Keempat } \\
\text { Kerakyatan yang } \\
\text { dipimpin oleh hikmat dan } \\
\text { kebijaksaan } \quad \text { dalam } \\
\text { permusyawaratan } \quad \text { dan } \\
\text { perwakilan }\end{array}$ & $\begin{array}{l}\text { Sila keempat menekankan bisnis pada penerapan sistem kemusyaw arahan dalam } \\
\text { pengambilan kebijakan di dalam praktik bisnis. Dalam internal bisnis, hal ini } \\
\text { mencerminkan kesempatan bagi semua karyawan terendah hingga level manajer } \\
\text { atas untuk ikut serta dalam mengeluarkan pendapat mereka dalam menyusun dan } \\
\text { mempertimbangkan kebijakan bisnis. Dalam sudut pandang eksternal, hal ini } \\
\text { memberikan kesempatan pada orang-orang di sekitar bisnis seperti pelanggan, } \\
\text { masyarakat sosial, komunitas, pemerintah, kreditur, dan lainnya, untuk turut } \\
\text { serta memberikan masukan dan pendapat mereka kepada bisnis sebagai } \\
\text { pertimbangan dalam menyusun kebijakan bisnis. Sila keempat mengeliminasi } \\
\text { praktik monopoli dimana bisnislah yang menentukan segalanya dan orang-orang } \\
\text { di sekitar hanya akan menerima apa kebijakan yang telah ditetapkan bisnis. }\end{array}$ \\
\hline
\end{tabular}

Jadi, dapat disimpulkan bahwa dalam mewujudkan suatu fokus bisnis pada kesejahteraan manusia harus dilandasi oleh adanya niat baik sebelumnya dari bisnis, sesuai dengan dasar deontologis (Keraf, 1998). Kemudian, dalam menurunkan konsep fokus pada kesejahteraan pada nilai-nilai yang lebih dapat diimplementasikan dengan mudah, ideologi Pancasila dapat dimasukkan sebagai dasar pendekatan oleh bisnis. Dengan berpegang kuat pada nilai-nilai ideologis sila kedua hingga kelima Pancasila, suatu model bisnis dalam fokus pada kesejahteraan manusia dapat diimplementasikan dengan lebih mudah.

\section{Fokus pada Kelestarian Alam (Planet)}

Fokus pada kelestarian alam merupakan salah satu pilar penyokong dari pondasi fundamental dari model bisnis yang baik dan bertuhan. Pilar ini menekankan bisnis pada perhatian untuk lebih bertanggungjawab kepada alam. Bisnis mengolah sumber daya yang diberikan oleh alam untuk menghasilkan keuntungan sehingga kewajiban bisnis adalah untuk memiliki rasa tanggung jawab kepada alam dengan upaya melestarikannya. Alam juga memberikan bisnis tempat untuk beroperasi dan berdiri, jadi keberadaan alam sangatlah penting bagi kelangsungan hidup bisnis. Harus diingat pula, apabila alam rusak maka kesejahteraan manusia akan terganggug olehnya. Jadi dapat dikatakan, pilar ini sangat terkait dengan upaya bisnis untuk mewujudkan pilar fokus pada kesejahteraan manusia. Bisnis yang tidak bertanggungjawab kepada alam akan otomatis merusak pondasi pilar ini dan pilar kesejahteraan manusia.

Bisnis ada yang secara langsung memanfaatkan hasil alam sebagai inti dari praktik bisnisnya, contohnya seperti bisnis sektor pertambangan dan energi, pangan, konstruksi dan transportasi. Bisnis-bisnis seperti itu memiliki tanggung jawab yang lebih besar untuk melestarikan alam karena mereka secara langsung mengeruk hasil alam sebagai bahan baku dalam bisnisnya. Hal ini apabila tidak dikendalikan dengan baik dan tidak disertai dengan kegiatan pelestarian alam maka akan dapat merusak alam. Kelestarian alam akan sangat berpengaruh pada kelangsungan hidup 
bisnis seperti ini ke depannya. Ada beberapa bisnis yang memang tidak mempengaruhi secara langsung pada kerusakan alam, contohnya seperti bisnis sektor perbankan. Bisnis seperti itu tidak secara langsung memberikan dampak pada kerusakan alam namun dapat memberikan kontribusi secara tidak langsung pada rusaknya alam. Sektor perbankan misalnya, sektor ini memberikan pendanaan pada bisnisbisnis yang memanfaatkan secara langsung alam dan memberikan bantuan untuk mewujudkan peningkatan produksi yang sama dengan memberikan kesempatan bagi bisnis-bisnis tersebut untuk mengkeruk alam lebih banyak lagi. Pengendalian dan keikutsertaan bisnis yang tidak memanfaatkan langsung alam akan sangat diperlukan untuk mewujudkan fokus pada kelestarian alam. Jadi, semua bisnis pada dasarnya memiliki kewajiban untuk ikut serta melestarikan alam.

Fokus pada kelestarian alam harus didasarkan pada suatu niat yang baik sesuai dengan pondasi dasar etika deontologi. Jadi, bisnis melakukan pertanggungjawabannya kepada alam bukan hanya sebagai bentuk pencitraan baik kepada publik ataupun mengikuti regulasi pemerintahan, melainkan memang didasarkan pada niat baik untuk sadar akan kewajiban untuk turut melestarikan alam. Fokus untuk melestarikan alam termasuk di dalamnya perhatian pada planet bumi, ekosistem, binatang dan tumbuhan. Bisnis lagi dijalankan hanya untuk mencari keuntungan, tetapi juga mempertanggungjawabkan keuntungan tersebut untuk kelestarian alam yang telah digunakan untuk menghasilkan keuntungan. Keuntungan bukan faktor kunci kesuksesan dari bisnis melainkan bagaimana keuntungan tersebut dapat mencerminkan pertanggungjawaban bisnis pula kepada kelangsungan hidup hewan, tumbuhan, ekosistem, dan planet bumi ini (Chwastiak \& Young, 2003). Memberikan perhatian pada kelestarian alam dapat pula diwujudkan dalam bentuk penciptaan gagasan produk bisnis yang inovatif dan mampu memberikan kontribusi positif terhadap perkembangan alam dan kelestariannya, dan bukan pada penurunan kelestarian bahkan meningkatkan kerusakan alam (Pederson, 2010). Hal ini dapat pula didukung dengan menciptakan strategi-strategi rekonstruksi alam, yang berarti mendorong alam yang telah digunakan untuk kembali pada keseimbangannya. Bisnis yang mampu mewujudkan kelestarian alam berarti mampu mewujudkan suatu hubungan harmonis dengan alam yang akan mengantarkan bisnis pada suatu kesejahteraan ke depannya (Krishna, 2010).

\section{Pondasi III : Konsep Pengungkapan Penuh (Full Disclosure Concept) sebagai Pondasi Luar (OuterFoundation) dari Model Bisnis}

Model bisnis yang baik dan bertuhan didasari pada pondasi dasar yakni konsep etika deontologis, dimana mensyaratkan suatu niat baik dalam praktik bisnis. Niat baik tersebut merupakan pedoman dasar yang harus dipegang teguh dalam mewujudkan model bisnis yang baik dan bertuhan. Sebagai lapis kedua dari model bisnis, perpaduan antara konsep TBL dan THK berperan sebagai pondasi fundamental 
yang memberikan pedoman dalam mengimplementasikan pondasi dasar agar lebih mudah diterapkan dalam praktik bisnis. Agar implementasi dari pondasi fundamental tersebut dapat lebih kuat, terlihat dan mampu diamati serta dievaluasi oleh publik maka pondasi lapis ketiga dibutuhkan berupa konsep yang mampu menurunkan pondasi dasar dan pondasi fundamental tersebut ke dalam suatu publikasi informasi yang dapat dinikmati oleh publik, pondasi terakhir ini ialah konsep pengungkapan penuh atau full disclosure concept.

Konsep pengungkapan penuh menekankan pada pengungkapan informasi oleh bisnis ke publik bukan hanya dalam bentuk laporan keuangan seperti laporan keuangan konvensional saat ini, melainkan berupa suatu rangkaian laporan lainnya yang terintegrasi satu sama lainnya dan mampu memberikan gambaran yang memadai tentang pelaksanaan pondasi dasar dan fundamental dari model bisnis. Laporan keuangan hanya merupakan gambaran mengenai keadaan ekonomi dari bisnis, dan itu kurang cukup, padahal bisnis sebenarnya juga harus dapat dilihat dengan dua pilar lainnya dari konsep THK dan TBL yakni informasi mengenai fokus bisnis terhadap kesejahteraan manusia dan pelestarian alam. Perwujudan dari konsep pengungkapan penuh dapat memberikan gambaran nyata terhadap publik mengenai perwujudan model bisnis baik dan bertuhan telah diterapkan dan diimankan oleh bisnis.

Satu hal penting dari konsep ini ialah bahwa walaupun informasi sudah dipublikasikan ke publik secara penuh, informasi tersebut haruslah dilahirkan dari penerapan pondasi dasar dan fundamental dari model bisnis. Hal ini berarti, konsep pengungkapan penuh hanya akan dapat mencerminkan pondasi terakhir dari model bisnis baik dan bertuhan asal pondasi dasar dan pondasi fundamental telah dipegang dan diimani oleh bisnis. Niat baik harus dilahirkan sebelumnya, lalu berpegang pada pedoman panduan antara konsep THK dan TBL, dan akhirnya bermuara pada publikasi informasi secara penuh. Untuk itu, agar konsep pengungkapan penuh ini dapat dipahami secara simpel, konsep pengungkapan penuh harus diturunkan dari ketiga pilar perpaduan antara THK dan TBL, yakni profit, people, dan planet. Ibarat suatu kesatuan dari pohon, akar adalah pondasi dasar yakni konsep etika deontologis, kemudian batang pohon adalah perpaduan konsep THK dan TBL yang bertugas menyambungkan akar kepada daun dan bunga, dan pondasi terakhir ini ialah dedaunan dan bunga dari pohon tersebut. Ia adalah apa yang paling mudah terlihat oleh publik, seperti layaknya bunga dan dedauan dari pohon.

Konsep pengungkapan penuh akan pilar keuntungan berarti menyediakan informasi berupa laporan keuangan yang lengkap, jelas, dapat diuji, dan memang mencerminkan keadaan ekonomi yang sebenarnya. Niat baik adalah pondasi dasar untuk mewujudkan konsep ini. Laporan Keuangan tidak boleh dimanipulasi dan mengandung kebohongan. Laporan keuangan juga harus menggambarkan mengenai proporsi dari keuntungan dan aset bisnis yang dialokasikan untuk mewujudkan fokus pada kesejahteraan manusia dan fokus pada kelestarian alam. Semua kebijakan, strategi, 
dan praktik bisnis yang berhubungan untuk mencerminkan fokus bisnis pada kesejahteraan manusia dan kelestarian haruslah diungkapkan dalam laporan yang berbeda dari laporan keuangan atau bahkan bisa berdiri sendiri namun terintegrasi satu sama lainnya. Intinya, bisnis harus menggambarkan bagaimana praktiknya untuk menyokong tiga pilar THK dan TBL tersebut. Kemudian kembali pada gagasan dasarnya, informasi dari konsep pengungkapan penuh harus dilandasi oleh adanya niat baik sebelumnya.

Pondasi dasar dan fundamental mungkin adalah ranah yang sulit untuk diakses oleh regulasi pemerintah. Oleh karena itu, pondasi ketiga, yakni konsep pengungkapan penuh, inilah yang lebih mudah untuk diakses oleh pemerintah untuk melahirkan regulasi-regulasi yang mengharuskan bisnis untuk terikat pada kewajiban pengungkapan informasi atas tiga pilar THK dan TBL tersebut. Namun, kembali lagi pada gagasan dasarnya, pondasi terakhir ini hanya akan dapat menjadi sempurna apabila pondasi dasar dan pondasi fundamentalnya telah dipegang kuat dan diimani oleh bisnis. Regulasi pemerintah akan menjadi suatu hal yang tidak berguna apabila pondasi dasar dan fundamental diabaikan oleh bisnis. Oleh karena itulah, ketiga pondasi dari model bisnis ini adalah tiga pondasi yang terpisah namun terkait dan terintegrasi satu sama lainnya. Pegangan yang kuat pada ketiga pondasi tersebut akan mencerminkan bisnis yang mampu mewujudkan model bisnis yang baik dan bertuhan seperti yang saya jelaskan dalam penjelasan ini.

\section{SIMPULAN}

Kebutuhan akan adanya suatu model bisnis yang baru merupakan suatu kepedulian untuk mengarahkan perhatian bisnis saat ini agar tidak hanya mementingkan keuntungan semata melainkan juga kepentingan dari pihak lain seperti karyawan, masyarakat sekitar dan alam. Model bisnis Baru yang dibentuk juga diharapkan mengandung nilai-nlai etis dan ketuhanan. Di dalam bagian pembahasan sebelumnya, model bisnis baru yang disusun di dalam artikel ini merupakan penyelarasan dari beberapa pendekatan konsep yakni dari Teori Etika Deontologis, Triple Bottom Line (TBL), kajian konsep budaya Tri Hita Karana (THK), Ideologis Pancasila dan Konsep Pengungkapan Penuh. Penulis menyebut model bisnis baru ini sebagai Model Bisnis Baik dan Bertuhan. Disebut sebagai model baik karena di dalamnya didasarkan pada aspek etis yang diturunkan ke dalam niat baik. Disebut sebagai model bertuhan karena pendekatan bisnis tidak semata hanya pada keuntungan, manusia, dan alam, melainkan juga memasukkan nilai keharmonisan bisnis dengan Tuhan di dalamnya. Keharmonisan dengan Tuhan tidak semata-mata hanya dijalankan berdasarkan pada sisi agama saja melainkan lebih luas yakni pada sisi spiritual dan memasukkan Tuhan di dalam segala aspek pertimbangan dan keputusan bisnis. Dimana dalam model tersebut, model tersusun dari tiga pondasi yang saling terkait satu sama lainnya, yakni pondasi dasar atau basic foundation, kemudian pondasi 
fundamental atau fundamental foundation, dan yang terakhir adalah pondasi konsep pengungkapan penuh. Inti dari model bisnis ini ialah pada pondasi dasarnya, yakni pendekatan deontologis, atau pendekatan tindakan berdasarkan niat baik atau nilai-nilai firman Tuhan. Disebut sebagai inti, karena pondasi ini memegang kekuatan dari pondasi-pondasi lainnya. Ibarat suatu pohon, pondasi dasar adalah akar, jika akar rapuh, maka pohon akan tumbang. Oleh karena itu, implementasi dari model bisnis ini mensyaratkan dipegang teguhnya pemahaman dan pengimanan terhadap pondasi dasar yakni pendekatan etika deontologis. Hal ini semakin dikuatkan dengan pendekatan ideologis sila pertama dari Pancasila, yakni Ketuhanan yang Maha Esa, dimana sila tersebut menekankan pada penyertaan nilai-nilai ketuhanan pada setiap keputusan dan tindakan dari bisnis.

Pondasi kedua yang membangun model ini menjadi lebih kuat ialah pondasi fundamentalnya, tersusun dari perpaduan konsep THK dan TBL. Kedua konsep ini mengarahkan fokus bisnis pada tiga pilarnya yakni: fokus dalam menciptakan kesejahteraan manusia, fokus melestarikan alam, dan fokus untuk menciptakan suatu keuntungan yang dapat dipertanggungjawabkan kepada Tuhan (responsible profit). Pengimplementasian ketiga pilar tersebut akan menghantarkan bisnis pada suatu hubungan yang harmonis kepada manusia di sekitar, alam dan kepada Tuhan. Hal ini akan memberikan suatu kesejahteraan atau welfare kepada bisnis, dimana di dalam welfare tersebut terdapat nilai sustainability development, yakni suatu orientasi yang dipaparkan oleh Elkington dalam konsep TBL. Perwujudan pilar fokus pada kelestarian alam akan tercipta dari perhatian bisnis terhadap planet bumi, tumbuhan, hewan dan ekosistem. Kemudian, pilar fokus pada kesejahteraan manusia akan tercipta dengan pendekatan ideologis bangsa yakni Pancasila sila kedua hingga kelima. Pilar kesejahteraan manusia dan kelestarian alam yang kuat akan berkontribusi pada terciptanya suatu keuntungan yang baik, halal, tidak haram, tidak ilegal, dan wajar kepada bisnis. Keuntungan seperti inilah yang mampu dipertanggungjawabkan bisnis kepada Tuhan, bukan keuntungan yang berasal dari tindakan rakus, haram ataupun melanggar hukum.

Pondasi terakhir dari model ialah pondasi pengungkapan penuh, dimana ibarat dalam pohon, ia seperti dedaunan dan bunga, yang mana analogisnya ialah bagian dari pohon yang paling pertama dan paling mudah untuk dilihat. Pondasi dasar dan fundamental tidak akan dapat dilihat oleh publik, oleh karena itulah pondasi ketiga muncul, berperan sebagai pondasi keterbukaan informasi ke publik. Kenapa? Karena publik wajib dan berhak menilai dan mengevaluasi mana bisnis yang harus dipertahankan dan mana bisnis yang buruk dan harus hilang atau diperbaiki. Pondasi ketiga ini tidaklah mudah untuk diterapkan, kekuatan pondasi dasar dan pondasi fundamental memainkan peran untuk menguatkan implementasi dari pondasi ketiga ini. Walaupun bisnis telah berkedok mempublikasi informasinya, namun pondasi dasar dan fundamentalnya diabaikan, maka sama saja model bisnis yang baik dan bertuhan ini tidak dapat diciptakan. Kembali lagi pada gagasan awalnya, pondasi dasar adalah pondasi 
terpenting di model ini, yakni niat baik dan ketulusan untuk menaati firman Tuhan. Akhirnya, untuk menurunkan implementasi dari pondasi ketiga ini, bisnis dapat mempublikasikan informasinya secara lengkap, jelas, handal, dan sesuai dengan kenyataan. Informasi yang dipublikasikan haruslah mencakup ketiga pilar fundamental, yakni pilar keuangan, pilar kesejahteraan manusia, dan pilar kelestarian alam. Dua bagan di bawah ini adalah muara dari hasil pembahasan dalam artikel ini. Bagan pertama menyajikan peta bagaimana model bisnis secara keseluruhan, dan bagan terakhir menyajikan analogi model layaknya sebuah pohon.

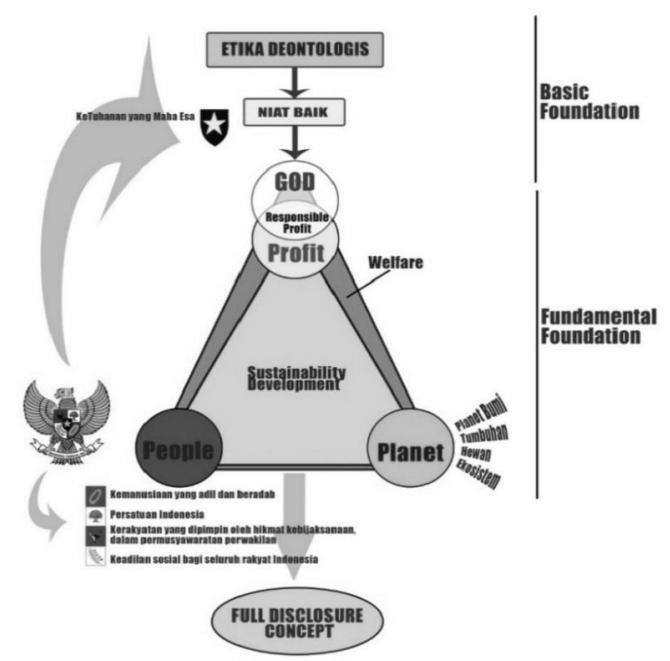

Gambar 2. Model Bisnis yang Baik dan Bertuhan

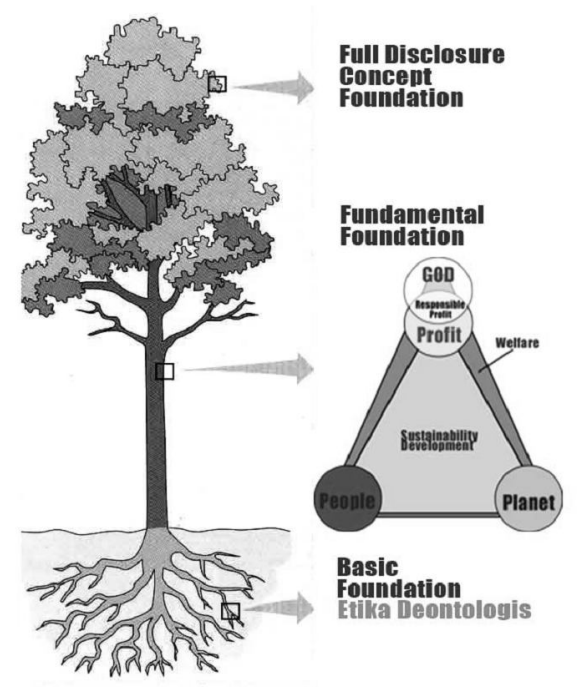

Gambar 3. Analogi Model Bisnis yang Baik dan Bertuhan 


\section{DAFTAR PUSTAKA}

Ahlstrom, D. 2010. Innovation and Growth: How Business Contributes. Exchange, 11-24.

Bertens, K. 2000. Pengantar Etika Bisnis. Yogyakarta: Kanisius (Anggota IKAPI).

Chwastiak, M., \& Young, J. 2003. Silences In Annual Reports.Critical Perspectives on Accounting, 533-552.

Elkington, J. 2004. Enter The Triple Bottom Line. Dalam ES TBL (hal. 1-16).

Fry, L., \& Slocum, Jr., J. 2008. Maximizing the Triple Bottom Line through Spiritual Leadership. Organizational Dynamics, Vol. 37, 86-96.

Keraf, D. S. 1998. Etika Bisnisx: Tuntutan dan Relevansinya. Yogyakarta: Penerbit Kanisius (Anggota IKAPI).xxxxx

Krishna, A. 2010.The Wisdom of Bali - The Sacred Scienceof Creating Heaven on Earth. Jakarta: Gramedia Pustaka Utama.

Pederson, E. 2010. Modelling CSR: How Managers Understand the Responsibilities of Business Towards Society.Journal of Business Ethics, 155-166.

Rakas, P. 2011. Global Business Ethics. Scientific Review Paper, 385-406.

Rogers, M., \& Ryan, R. 2001. The Triple Bottom Line fo Sustainability Community Development. Journal of Local Environment Volume 6, 279-289.

Subadra, I., \& Nadra, M.N. 2006. Dampak Ekonomi, Sosial-Budaya, dan Lingkungan Pengembangan Desa Wisata di Jatiluwih-Tabanan. Jurnal Manajemen Pariwisata, 46-64. 